\title{
Women's Medicine, Women's Magic: The Old English Metrical Childbirth Charms
}

\author{
L. M . C, WESTON \\ California State University, Fresno
}

What remains to us of Anglo-Saxon medicine is less a unified system than a palimpsest (or perhaps a collage) of traditions Greco-Roman and Germanic, literate and oral, Christian and pagan. The creators of the manuscripts usually called Lacnunga (Harley 585) and Leechbook (Regius $12 \mathrm{D}$ xvii), which contain between them the bulk of extant medical remedies, consciously situate their works within a classical scientific tradition. Leechbook cites Pliny; both it and Lacnunga draw upon Alexander of Tralles. ${ }^{1}$ The first two of Leechbook's three parts follow the pattern of classical texts by listing prescriptions for external and internal disorders from the head down; Lacnunga accompanies an Old English translation of the Herbarium of Apuleius.

Within these frames-classical and scientific even in their project of systematically compiling remedies as written texts-the manuscripts place empirical prescriptions based on local as well as originally Mediterranean materia medica, and a number of nonscientific charms and amulets both Greco-Roman and Germanic. These magical remedies, especially numerous in Lacnunga, locate the manuscripts at the point where oral and textual traditions meet even more explicitly than do the scientific prescriptions. Their talismans need to be literally reinscribed on parchment, cloth, or wax: the written text itself constitutes materia medica. Other charms and prayers lie dormant on the page until said aloud: their efficacy is wholly oral and performative.

Such magical formulas invoke both Christ and Woden-sometimes, as with the Nine Herbs Charm, in the same incantation. Earlier

1. Godfrid Storms, Anglo-Saxon Magic (The Hague, 1948), pp. 14-15, 19. For a more detailed account of Anglo-Saxon medicine's debt to classical science, see M. L. Cameron, "The Sources of Medical Knowledge in Anglo-Saxon England," Anglo-Saxon England 11 (1983): 135-55. Both Harley 585 (Lacnunga) and Regius $12 \mathrm{D}$ xvii (Leechbook) are manuscripts in the holdings of the British Library.

(C) 1995 by The University of Chicago. All rights reserved. 0026-8232/95/9203-0001 $\$ 01.00$ 
commentators like Godfrid Storms spoke of Christian interpolations; more recent scholars locate the charms within a tradition of Christian magic, the rise of which has been documented most recently by Valerie Flint. ${ }^{2}$ Internal evidence suggests Lacnunga's monastic origin: J. H. G. Grattan and Charles Singer attribute the piecemeal compilation of the text to, among others, "the medicus of a monastery" and "the inmate of some small monastery in the North in which Irish influence survived." The prevalence of Christian liturgy as well as the repeated inclusion of masses and paternosters in its charms leads Karen Jolly to conclude that the most likely Anglo-Saxon magicomedical practitioner was, as often as not, a village priest. She notes that most of the rituals using masses or litanies are pitted against illness of supernatural origin; a priest and only a priest, she posits, could bring against evil spirits his authority as mediator between God and man, this world and the other. ${ }^{4}$ Less obviously Christian charms, however, seem to invoke the presence of that other magical technician, the shaman. For Stephen Glosecki, the charm "Against a Sudden Stitch" offers the most pronounced instance of shamanic healing, for "whoever composed this charm-a preliterary and preChristian doctor, most likely-recounts direct experience of the dreamtime" and of spiritual combat against otherworldly enemies. ${ }^{5}$

Among these contrasting influences, however, we should identify yet one more: gender. Both manuscripts encode a male textual tradition. This is particularly true of Leechbook, where a Latin poem names an owner, Bald, and his scribe, Cild, who combined previous books compiled by editors named Oxa and Dun. Lacnunga, too, invokes the male as the normative voice, except in its metrical childbirth charm(s). In these verses, known to modern scholars as "For a Delayed Birth," as nowhere else, a woman speaks on her own behalf, suggesting that we might well ask who, among the Anglo-Saxons, had the primary

2. Valerie I. J. Flint, The Rise of Magic in Early Medieval Europe (Princeton, N.J., 1991).

3. J. H. G. Grattan and Charles Singer, Anglo-Saxon Magic and Medicine (London, 1952), pp. 19, 21.

4. Karen Louise Jolly, "Anglo-Saxon Charms in the Context of a Christian World View," Joumal of Medieval History 11 (1985): 279-93; see also her later "Magic, Miracle, and Popular Practice in the Early Medieval West: Anglo-Saxon England," in Religion, Science and Magic: In Concert and in Conflict, ed. Jacob Neusner, Ernest S. Fredrichs, and Paul Virgil McCraken Flesher (New York, 1989), pp. 166-82.

5. Stephen Glosecki, Shamanism and Old English Poetry (New York, 1989), p. 14

6. E. V. K. Dobbie, The Anglo-Saxon Minor Poems (New York, 1942), Pp. 123-24; all citations of the charms are from this edition. These charms have also been edited by Felix Grendon, The Anglo-Saxon Charms (New York, 1909), pp. 206-9; Storms, pp. 196-203; and Grattan and Singer, pp. 189-91. 
responsibility for healing, and most especially for managing childbirth.

These responsibilities are less documented than those of male doctors like Bald, Oxa, and Dun, at least partly because female healing practices constituted less a professional specialty than an inseparable part of everyday domestic duties and participation in the community of women. Despite the masculine ordering principle responsible for the preservation of the medical remedies as we now have them in the Leechbook and Lacnunga, and despite the identification by name of three physicians, all male, it seems at least possible that women contributed much to medical wisdom, with the metrical childbirth charms being only the most obvious instance. We may, indeed, go so far as to suggest the existence of an identifiable female medical tradition, one which came to be partially appropriated by male authorities even as it was viewed with suspicion. Audrey Meaney documents women's healing function within the household, and documents, too, the less benign view of this healing, especially where it involved charming, taken by churchmen like Aelfric. ${ }^{7}$ Glosecki, though identifying his shaman as normatively male (and connecting him to similarly male warriors and smiths), notes the existence of shamankas and indeed "the apparent association of shamanizing with women in saga lore." 8

We may assume, however, that women's healing would not have consisted wholly of belief in and service to supernatural powers. M. L. Cameron, championing the commonsense rationality of many of Leechbook's and Lacnunga's herbal remedies, argues that use of copper or iron utensils displays not superstition but an empirical knowledge of chemical reactions. Cameron assumes the masculinity and professionalism of the healer. He speaks of "materials available to the Anglo-Saxon physician, drawn from both his ancestral pagan Teutonic background and from the Mediterranean culture introduced by Christian missionaries." ${ }^{9}$ But who else, we may ask, would have known such chemical reactions? Women - at least some of them-could have gained the kind of common sense to which Cameron has drawn our attention from everyday experience with health problems, in the same way that they

7. Audrey L. Meaney, "Women, Witchcraft and Magic in Anglo-Saxon England," in Superstition and Popular Medicine in Anglo-Saxon England, ed. D. G. Scragg (Manchester, 1989), pp. 9-40. For a discussion of medieval women's participation in their own healing, see Monica Green, "Women's Medical Practice and Health Care in Medieval Europe," in Sisters and Workers in the Middle Ages, ed. Judith M. Bennett (Chicago, 1989), pp. $39-78$.

8. Glosecki, p. 100.

9. M. L. Cameron, “Anglo-Saxon Medicine and Magic," Anglo-Saxon England 17 (1988): 191-215, 211. 
learned, for example, the unfortunate consequences of using an iron pot to preserve fruit or the necessity of using one if onion skins are to yield an olive green dye. A few potions and charms found their way into medical texts. Many more healing salves and strengthening brews for women in labor were no doubt passed on through oral tradition, from mother to daughter, along with recipes, instructions for cheese-making, pickling and preserving, and making dye and soap.

While such empirical remedies escape their original gendered social context once they are transcribed into a manuscript, the metrical childbirth charms-indeed any remedies incorporating ritual or otherwise requiring performance-retain more of their gendered speaking voice and their connection to an oral tradition. Granted, this connection is not a simple one. The very presence of oral "texts" in a manuscript marks them as appropriated; so does the existence of women's texts in an otherwise male context. They are by no means pristine remains of a primary oral tradition, though we can only speculate about how they found their way into Lacnunga. Should we posit a female scribe as first source, or a double monastery as their first home? ${ }^{10}$ How many transcriptions have the charms seen? These questions remain unanswerable in the present state of our knowledge, which depends, of course, on the accessibility of written texts. We can, nevertheless, hear a woman's voice behind the words that the charm records.

The manuscript offers five metrical passages divided by accompanying ritual instructions in prose and by three parallel introductory formulas, each repetition marked by an initial capital:

Se wifman se hire cild afedan ne mæg...

Se wifmon se hyre bearn afedan ne mæge ...

Se wifman se ne mæge bearn afedan ...

The woman's inability to afedan hire cild may be variously translated "nourish her child in her womb," "bring her child to term," and "nurse her child" after its birth. Though E. V. K. Dobbie, Felix Grendon, Godfrid Storms and J. H. G. Grattan, and Charles Singer all edit them as one, the evidence would suggest that the scribe has in fact gathered together three separate but related remedies. Their shared rubric subsumes all of childbearing from conception to weaning, the entire period during which the child depends upon the nurturance and po-

10. Elsewhere in Lacnunga a mostly Latin prayer-remedy against pestilence begs God libera illam (free this woman). The Latin is followed by a passage of garbled Irish prefaced brigitarum. Grattan and Singer suggest that the plural nominative brigitae ("brigits") are perhaps nuns of Saint Brigit (p. 201). 
tency of its mother's body. While the manuscript commonly collects alternative remedies under repeated headings, it does not elsewhere conflate multiple complaints in this fashion. The conflation as well as the rubric implies that these are women's concerns, things beyond the male physician's domain. ${ }^{11}$ However much scribal intervention divides the texts from their original performance, then, the metrical childbirth charms nevertheless evoke a female oral tradition existing alongside of and in dialogue with the dominant male traditions-shamanic, priestly, and scientific-within the manuscript and within the greater context of Anglo-Saxon England.

The history of gender relations in the middle ages is a complex one. Nevertheless, as close students of the period like Judith Bennett have shown, we can generalize that men and women formed effectively two communities within the greater village whole, and we may deduce that the separation would have had profound ideological and psychological consequences. ${ }^{12}$ James W. Earl suggests some of the effects on the male community as he addresses "The Role of the Men's Hall in the Development of the Anglo-Saxon Superego" and the definition of heroic behavior. ${ }^{13}$ By such definitions, for example, Beowulf s Scyld Sceafing can be judged god cyning, and the Cotton Maxims can decree that

Ellen sceal on eorle, ecg sceal wio hellme hilde gebidan.

(Courage shall be in the warrior, edge shall against helmet experience battle. $)^{14}$

As Mary Douglas points out, "ideas about separating, purifying, demarcating and punishing transgressions have as their main function to impose a system on an inherently untidy experience. It is only by exaggerating the difference between within and without, above and below,

11. A section now unfortunately missing from Leechbook is described as containing "remedies against natural obstruction of women and all infirmities of women," thus similarly separating women's medicine from the main body of the text. The rubric continues "if a woman cannot bear a child or if the child is dead in the woman's womb, or if she cannot bring it forth, place on her girdle the prayers that are mentioned in these leechbooks" (Storms [n. 1 above], pp. 202-3). The physician/priest is thus distanced from his patient through the proxy of a talisman. Another entry in Lacnunga, headed "gif wif ne mage bearn beran," contains only a Latin formula, "solve iube deus ter catenis." Grattan and Singer construe it as "'Rejoice, loose their chains, O Lord' thrice" (pp. 186-87). They also disregard the caption and consider it part of the previous charm for an elf-shot horse.

12. Judith M. Bennett, Women in the Medieval English Countryside (New York, 1987).

13. James W. Earl, "The Role of the Men's Hall in the Development of the AngloSaxon Superego," Psychiatry 46 (May 1983): 139-60.

14. Dobbie, Pp. 55-57, lines 16-17a. 
male and female, with and against, that a semblance of order is created." 15 Where the men's hall occupies the cultural center and defines that "semblance of order," women and women's lives outside the hall in the places where they cooked the food, wove the cloth, and bore the children - all processes, as Sherry Ortner argues, transforming nature into culture-represent a potentially dangerous ambiguity. ${ }^{16}$ Given the logical oppositions male/female and human/nonhuman, if the norm for human is male, where does woman stand if not on the boundary between the human hall and the nonhuman wilderness? The women's world may thus appear like the shaman's in its liminality, but this liminality is constant rather than transitory, literal rather than metaphorical.

Indeed, to define women's reality as liminal at all may be to stand at the (male) cultural center and look out at women, not to look with women. So Caroline Walker Bynum argues against Victor Turner's paradigm, noting how often the imagery and narratives of later medieval female spirituality are marked by continuity or intermediacy, how rarely they invoke reversals and the oppositional structure upon which depends the genuine liminality of religious conversion, of the warrior's or the wise man's initiation, and of the shaman's magical battles. ${ }^{17}$ Bynum's critique prompts us to inquire about the negotiation of cultural paradigms by women (specifically the creators and performers of the metrical childbirth charms) as well as by men (including the compilers of Lacnunga and Leechbook) who construe female behavior. How do women negotiate the healer/shaman's link to the warrior? To what extent do the words of women not only express female experience but also recognize (and perhaps use or even subvert) women's images in the men's hall?

15. Mary Douglas, Purity and Danger: An Analysis of Concepts of Pollution and Taboo (London, 1966), p. 4.

16. Sherry B. Ortner, "Is Female to Male as Nature Is to Culture?" in Woman, Culture and Society, ed. Michelle Zimbalist Rosaldo and Louise Lamphere (Stanford, Calif., 1974), pp. 67-87.

17. Caroline Walker Bynum, "Women's Stories, Women's Symbols: A Critique of Victor Turner's Theory of Liminality," in Anthropology and the Study of Religion, ed. Robert L. Moore and Frank E. Reynolds (Chicago, 1984), pp. 105-25. Following Nancy Chodorow, Bynum finds psychological correlates for cultural and social paradigms: male oppositional definitions and consequent liminalities reinforce the experience of separation from the world of the mother and an artificial initiation into the world of adult men. Female continuity reiterates the continuance of life in the mother's world and natural initiation into womanhood. Female religious life melds spirituality with ordinary domestic and social reality: "Women's rather 'structureless' religion simply continued their ordinary lives (whose ultimate status they usually did not control), just as the economic work of 'holy women' - weaving, embroidery, care of the sick and small children-continued women's ordinary experience" (p. 117). 
Anglo-Saxon wise men, both priests and shamans, working from the symbolic center to distinguish the known from the unknown and thus to control the world around them, set women's indeterminacy within and yet against their own distinctions. The only woman in the Cotton Maxims, for example, appears with the thief and the thurse (or troll) as threats to the order established by the rest of the wise man's utterance. Her crime, seeking a lover purh dyrne crafte (by secret craft), Audrey Meaney suggests, may in fact be witchcraft, using magical means to take control of her own sexuality. ${ }^{18}$ The poem calls her an ides, a poetic epithet for a human woman cognate with the Old Norse disir and the Old High German idisi, both of which denote supernatural creatures.

This is one of many references that confound human and supernatural women. Helrunas may be human sybils or evil spirits. Burgrunas may be wisewomen of the community, but they may also be supernatural guardian spirits. Human wicce may possess inherent, possibly hereditary magical powers; or they may simply practice sorcery. Then again, they may be fully supernatural hags. When Wulfstan, for example, couples wicce with welcyrge, perhaps echoing a traditional alliterative collocation, his witch seems supernatural; yet both nouns designate human beings. ${ }^{19}$

Truly, fear and awe before the possibility of women's inherent contact with the supernatural are deep-rooted. Much-probably too much-has been made of Tacitus's assertions about the prophetic power and prestige of Germanic women. Glosecki speculates that "with Germanic as with many other tribal peoples, women were considered gifted in supernatural arts partly because of menstruation, which connects them with the cosmic rhythm of lunar cycles." ${ }^{20}$ As Jenny Jochens notes, a reputation for supernatural knowledge may stem less from social deification than from difference: "Unable to choose between political alternatives or fearful of their outcome, men occasionally sought advice from 'the others." 21 Paul Bauschatz likewise sketches the mythological and symbolic linkage of women and prophecy: "Women were more in touch with the forces beyond this

18. Audrey L. Meaney, "The Ides of the Cotton Gnomic Poem," in New Readings on Women in Old English Literature, ed. Helen Damico and Alexandra Hennessy Olsen (Bloomington, Ind., 1990), pp. 158-75.

19. Christine Fell, Women in Anglo-Saxon England (Bloomington, Ind., 1984), p. 31; Meaney, "Women, Witchcraft and Magic in Anglo-Saxon England" (n. 7 above), p. 15.

20. Glosecki (n. 5 above), p. 100.

21. Jenny Jochens, "Voluspa: Matrix of Norse Womanhood," Journal of English and Germanic Philology 89 (1989): 344-62, quote on 360. 
life," the forces of the natural, animal world and of Urd's Well, the world of Wyrd, the realm of the unknown and uncontrolled. ${ }^{22}$

According to continental sources, some wandering wives join in "wild hunts" with night-flying hags and spirits of the dead. Or so texts like the Canon Episcopi record: "Some wicked women perverted by the devil, seduced by illusions and phantasms of demons, believe and profess themselves, in the hours of the night, to ride upon certain beasts with Diana, the goddess of pagans, and an innumerable multitude of women, and in the silence of the dead of night to traverse great spaces of earth." 23 Burchard of Worms likewise asks women in his Corrector: "Do you believe... that, in the silence of the night, when you are stretched out upon your bed with your husband's head upon your breast you have the power, flesh though you are, to go out of the closed door and traverse great stretches of space with other women?"24 He gives Diana a Germanic identity, that of Holda, a vague supernatural figure who, with Percht and other similar "Winter Goddesses" as well as the Celtic Cailleach, the earlier continental Matronae, and perhaps the Anglo-Saxon Mothers of Bede's modranecht, inhabits storm, night, and the wild places whence she dispenses knowledge of female mysteries such as spinning and midwifery. ${ }^{25}$ In references like these Carlo Ginzburg sees evidence of archaic shamanistic practices surviving into medieval folk-belief in the form of "a primarily female ecstatic religion, dominated by a nocturnal goddess." 26 Whatever the reality of Holda cults, or even the reality of dreams of riding with Holda, there can hardly be a better image of the female community as separate, as other.

The mihtigan wif (powerful women) battled and exorcised in the Anglo-Saxon charm "Against a Sudden Stitch" first appear riding over the hlawe, "the burial mound"-symbolically marking the limits of human (or at least male) life and knowledge. Even the identity of the charm's riders defies easy knowledge and control: they may be ylfa (elves), or esa (aesir), or hagtessan (hags). By "aesir" could be meant valkyries, or perhaps a figure like the Old Norse Freyja who, valkyrie-

22. Paul Bauschatz, The Well and the Tree: World and Time in Early Germanic Culture (Amherst, Mass., 1982), p. 65.

23. Henry C. Lea, Materials toward a History of Witchoraft (New York, 1957), pp. 178-79.

24. Flint (n. 2 above), p. 123.

25. For Germanic "Winter Goddesses," see Lotte Motz, "The Winter Goddess: Percht, Holda, and Related Figures," Folklore 95 (1984): 151-66, and her earlier "Sister in the Cave: The Staure and the Function of the Female Figures of the Eddas," Arkiv for nordisk Filologi 95 (1980): 168-82. For Celtic analogues, see Anne Ross, "The Divine Hag of the Pagan Celts," in The Witch Figure, ed. Venetia Newall (London, 1973), pp. 139-64.

26. Carlo Ginzburg, Ecstasies: Deciphering the Witches'Sabbath (New York, 1991), p. 122; cf. Flint, pp. 122-25 
like, commands a portion of the slain and, witch-like, rules the magic of the seidr. ${ }^{27}$ In the glosses, as Katherine Morris observes, hagtesse overlaps with wealcyrige, especially in naming a creature of uncontrollable fury or frenzy. Other glosses like ganea (whore) link witches' fury with female sexuality, the area of female life most remote from male control and consequently that most fraught with danger. ${ }^{28}$ We may well wonder whether such images, replete with such dangerous and frightening ambiguity from the perspective of the men's hall, might not contrarily empower the women outside, especially for the management of their own pregnancies and childbirths.

As Adrian Wilson has documented, until the advent of "modern medicine," childbearing followed "a pervasive popular ritual that was maintained by (and probably had been created by) the women of England." ${ }^{29}$ The actual birth was an exclusively female ceremony: the mother-to-be selected a number of women to attend her under the direction of the presiding midwife. Their preparation of the lying-in chamber re-created it as sacred space. The caudle (a mixture of ale, milk, honey, and herbs effective in inducing labor and easing pain) provided a sacred drink. ${ }^{30}$ The woman remained secluded within this female-constituted world until her "churching," an official (and malemanaged) ecclesiastical ceremony. Though later explained as an act

27. Lotte Motz, "Freyja, Anat, Ishtar and Inanna: Some Cross-Cultural Comparisons," Mankind Quarterly 23 (1982): 196.

28. Katherine Morris, in "Witch Words: The Origin and Background of German Hexe," General Linguistics 27 (1987): 82-95, in fact champions an etymological connection between hagtesse, earlier *hagazussa, not just with the widely accepted "hedgewoman" but also with a postulated *haga $(n a)$, (female) genitalia (p. 92). Her later "The Lascivious Witch," Mankind Quarterly 26 (1986): 285-303, further discusses the yoking of witchcraft and fornication. Motz sees Freyja's association with sexual union as linked less with the procreation we might expect from a "fertility" goddess than with sex for its own sake or perhaps for the sake of the frenzy arising from intercourse as an inducement to shamanic ecstasy ("Freyja, Anat, Ishtar and Inanna," pp. 201-2). In this she foIlows Peter Buchholz's speculations in "Shamanism-the Testimony of Old Icelandic Literary Tradition," Medieval Scandinavia 4 (1971): 7-20, concerning the nature of ergi and its function in regard to the seidr. Glosecki (n. 5 above) takes pains to refute Eliade's earlier assertions that the seidr was a female specialty, though he wonders whether, given women's proverbial connection with magic, "rather than being beneath men, the seidr may not have been above them, originally" (p. 101).

29. Adrian Wilson, "Patient or Participant? Seventeenth Century Childbirth from the Mother's Point of View," in Patients and Practitioners: Lay Perceptions of Medicine in Preindustrial Society, ed. Roy Porter (Cambridge, 1985), pp. 129-44, 133.

30. For discussion of caudles, see Jacques Gelis, History of Childbirth (Boston, 1991), pp. 114-15 and 152-53. Hillary Spurling, Elinor Fettiplace's Receipt Book (London, 1986), pp. 86-87 and 217, provides two examples preserved within a commonplace book collection of recipes, formulas, and domestic advice bequeathed from mother to daughter in one Renaissance English family. 
of thanksgiving, the churching has its liturgical roots in Leviticus's injunction that the childbearing woman needs ritual purification: birth renders her impure and therefore dangerous or (from a different perspective) powerful.

Hence, by looking through female-defined rituals, by looking with women at images of female ambiguity and power, we can best interpret the women's metrical charms which appear in Lacnunga amid other, more male-identified, incantations and remedies.

The first charm requires three ritual acts, each accompanied by ceremonial speech. The first incantation must be repeated by the woman three times as she steps over the grave of a dead man:

Đis me to bote pære lapan lætbyrde,
pis me to bote pære swæran swærbyrde,
pis me to bote pære ladan lambyrde.
(This my remedy for hateful slow birth,
this my remedy for heavy difficult birth,
this my remedy for hateful imperfect birth.)

The verbal magic lies in the triple (actually, ninefold) repetition of "pis me to bote ... -byrde," the echo and alliteration of lapan lat-and laðan lam-, the polyptoton of swaran swar-. This verbal technology is common to other metrical charms, irrespective of gender. ${ }^{31}$ Marie Nelson interprets the formula as an act of defiance, a naming and exorcism of "the three great threats to the life of her unborn child." 32 By stepping over the grave, Nelson suggests, the mother transfers the influence of evil spirits away from herself. But the woman names no evil spirits, and her words turn her magical force not outward, as in other charms, but back upon herself: "pis me to bote." The ritual will bear a different interpretation, one based in female negotiations of the mythic images discussed above. Passing over the grave, she makes herself a benign mihtigan wif (to borrow a phrase from "Against a Sudden Stitch"). Those who lead the wild hunts also protect birth; perhaps the souls of the unborn issue from the same Otherworld of the dead. ${ }^{33}$ The grave marks a boundary between the living and the non-

31. See, among other articles, Judith Vaughan-Sterling, "The Anglo-Saxon Metrical Charms: Poetry as Ritual," Journal of English and Germanic Philology 82 (1983): 186-200; and L. M. C. Weston, "The Language of Magic in Two Old English Metrical Charms," Neuphilologische Mitteilungen 86 (1985): 176-86.

32. Marie Nelson, "A Woman's Charm," Siudia Neophilologica 57 (1985): 3-8, quote on 3 .

33. Gelis discusses continental folklore concerning Holda's wild hunt as embracing the souls of both dead and unborn children. For this reason, "before the human intercourse which would humanize and 'familiarize' the future offspring came a coupling of 
living, this human world and the other: the woman bearing a not-yetliving child embodies a similar boundary within herself.

In the next part of the charm a complementary act completes her passage with her child from potential to actual life. Here she steps over a living man (her husband) saying,

up ic gonge, ofer pe stæppe
mid cwican cilde, næles mid cwellendum,
mid fulborenum, næles mid fægan.
(Up I go, step over you
with a living child, not a dead one,
with a full-born one, not a doomed one.)

The woman and the child within her womb cross another boundary; indeed, the woman herself becomes the boundary her child will pass through by moving from nonlife to life. Her formula once more depends for its magical force upon the phrase-initial adverbs in "up ic gonge, ofer pe stæppe," the repetition of mid... nales mid, the alliteration and chiastic endings of cwican and cwellendum, fulborenum and fagan.

The third and final part of this charm reinforces the ritual's private, unofficial character even as it places the woman within a larger (and explicitly Christian) community. When she feels that the child lives, the mother-and for the first time she is so named, seo modor rather than pat wif-goes to the church. Standing before the altar she announces, "Criste, ic sæde, pis gecyped" (by Christ, I have said, this is manifested). All previous actions have been in the present, the tense of process and becoming; here gecyped and even sade (which should logically be present) are in the past, the tense of what has become established. Her actions, verbal and nonverbal, look ahead to the churching which will end her confinement. Through her charm the mother has bespoken herself potent and fertile; her words have made her womb a site of transformation, of the nonliving becoming living, the inchoate taking form.

The second childbirth charm is less complex. The woman who cannot bring a child to term, that is, who has had a stillbirth, "genime heo sylf hyre agenes cildes gebyrgenne dæl" (takes herself some earth from her own child's grave). The instructions thus underscore the woman's agency and personal power. She wraps this earth in black

the woman with the forces of nature. A woman paying her visit to the blessed spring, the sacred stone or the holy tree was attempting to capture the essence, the principle of the child" (p. 36). 
wool and sells it to a merchant. Her words, like those of the first charm, pronounce the action they accompany:

\author{
ic hit bebicge, ge hit bebicgan, \\ pas sweartan wulle and pysse sorge corn. \\ (I sell it, you buy it, \\ this black wool and this sorrow's seed.)
}

Alliteration binds sweartan to sorge in the second line, and interlaced word-endings $-e$ and $-n$ tie both lines together. The repetition of $b e-$ bicgan, both "sell" and "buy," marks the present movement of what has happened (the past stillbirth) beyond the boundaries of the village, into the unknown - the merchant's marginality answering the woman's own. Does the black wool suggest a woman's spinning and weaving? ${ }^{34}$ It surrounds the "seed" of her sorrow; perhaps this metaphorically re-creates her pregnancy. If so, this gesture returns her to potent possibility.

The third and last childbirth charm aids the woman who cannot breastfeed her child. First she must take up in her own hand the milk of a cow of one color, sip it, and carry it in her mouth to a stream of running water. She must spit the milk out, then drink a mouthful of water from the same hand, swallowing it this time. The cow and the stream both provide nurturing liquids; by sipping the milk she feeds herself as she wishes to feed her child, and by transferring the milk to the water she physically enacts the desire that milk will flow as abundantly as the stream. The woman makes herself an intermediary to her own desire: she swallows the water's abundance. As in the first charm, the woman moves between two places: the cow in the byre at home and the stream that perhaps marks the boundary of the settlement.

34. Evidently some churchmen feared that weaving, a traditionally female occupation carried out in the bowers away from male control, could become the occasion for illicit magic. Burchard, e.g., inquires, "Have you been present at, or consented to, the vanities which women practice in their woolen work, in their weaving, who, when they begin their weaving, hope to be able to bring it about that with incantations and with their own actions that the threads of the warp and the woof become so intertwined that unless someone makes use of their other diabolical counter-incantations he will perish totally?" (Flint [n. 2 above], p. 227). In chapter 157 of Njal's Saga (Einar Sveinsson, ed., vol. 12 of Íslenzk Fornrit [Reykjavik, 1954]; Magnus Magnusson and Herman Pálsson, trans. [Harmondsworth, 1960]), valkyries weave the destinies of fighting men before the Battle of Clontarf; and in chapter 11 of the Orkneyinga Saga (Finnbogi Gudmundsson, ed., vol. 34 of Îslenzk Fornrit [Reykjavik, 1965]; Hermann Pálsson and Paul Edwards, trans. [Harmondsworth, 1978]), Earl Sigurd's sorceress mother embroiders him a banner which brings victory to her son but death to his unfortunate standardbearers. 
After swallowing she announces,

gehwer ferde ic me pone mæran maga pihtan,
mid pysse mæran mete pihtan;
ponne ic me wille habban and ham gan.
(Everywhere I carried with me the famous strong
son, with this famous strong meat,
then I want to possess myself and go home.)

Her words gain power through repeating maran ... pihtan, while varying maga with mete. They also vary past and present tenses: the past carrying of the child, which she ferde, and the present desired possession of the milk, what she wille habban. Nelson draws attention to the reflexive me habban in the final line and paraphrases, "I want to have control over my own body." 35 This reading is apt: the mother does desire control, the power within herself to create and provide milk as she has created the life of her child.

Physically this desire translates into further motion. Without looking back, the charm says, she has gone to the stream, and without looking back she must return home, going to a house other than her own home and receiving food there. Carrying within herself the power of flowing nurturance and sharing, too, some of the stream's symbolic marginality, she becomes the recipient of some other woman's nurturing. As in the final stage of the first charm, she rejoins the community while still embodying her potent ambiguity.

Individually, each of these charms empowers the childbearing woman and, indeed, the female community to which she belongs. She takes responsibility for her own healing; she speaks words no one else can speak for her. But these charms are exceptions in the magicomedical manuscript tradition. Their oral and female healing practices have been appropriated and segregated within male writing and male classification of knowledge in hierarchical systems. Their difference from male healing practices is all the more visible when these vernacular charms from Lacnunga are contrasted with the Latin childbirth charm found in MS. Junius $85 .{ }^{36}$ There someone else-perhaps a priest-must write magical words upon virgin wax; the resulting amulet is bound under the mother's right foot. A literate authority thus acts for and upon his patient. The Junius text itself invokes biblical models for safe deliveries:

35. Nelson, "A Woman's Charm," p. 5.

36. Charms from British Library manuscript Junius 85 are edited by Storms (n. 1 above), p. 283, and Grendon (n. 6 above), p. 159. 
Maria virgo peperit Christum, Elisabet sterilis peperit Iohannem baptistam.

Adiuro te infans, si es masculus an femina, per Patrem et Filium et Spiritum sanctum, ut exeas et recedas, et ultra ei non noceas neque insipientam illi facias. Amen.

Videns dominus flentes sorores Lazari ad monumentum lacrimatus est coram Iudeis et clamabat:

Lazare veni foras.

Et prodiit ligatis manibus et pedibus qui fuerat quatriduanus mortuus.

(Mary, virgin, brought forth Christ; Elizabeth, sterile, brought forth John the Baptist. I adjure you, infant, whether you be masculine or feminine, by the Father and the Son and the Holy Spirit, that you awaken and move, and no longer do any injury or foolishness. Amen. The Lord, seeing the sisters of Lazarus weeping at the tomb, wept in the presence of the Jews and cried out: Lazarus come forth. And he came forth with hands and feet bound who had been four days dead.)

The healing charm-"prayer" might be more accurate-finds its model in exorcism: the child to some extent "possesses" his mother (the child's models, Christ, John, and Lazarus, are all male, so she is rightly his mother) and thus must be induced to depart by biblical precedents and the innate force of Latin as the language of the sacred. The as yet unborn child is poised, liminally like the figure of Lazarus, between life and death; the woman has become more a vessel than a participant. Indeed birth here partakes of the miraculous, not the natural, and if the child is to come forth like Lazarus, the woman must be his tomb. Far from actively managing the birth, the women around the mother become, like sisters of Lazarus, audience rather than actors. Only the Lord acts: His words, inscribed by His vicar on the talisman, accomplish the miracle. Ironically, however, even as the charm grants the power of the priest's male world, it reinforces his exclusion from the female realm; he enters the birth chamber only through the proxy of the talisman.

The contrasts are clear. Through the vernacular charms' magically powerful alliteration and repetition the female speaker creates desired situations for herself. Her charms recognize and use boundaries between the human and the nonhuman for their power, but they are not exorcisms: no elf or demon is battled or blamed. This feature in itself makes the metrical childbirth charms quite different from not only the Latin but also other vernacular charms embodying underlying structures of opposition and spiritual warfare, as Nigel Barley, Stephen Glosecki, Karen Jolly, and Marie Nelson all observe. Barley notes that "for the Anglo-Saxons ... there is a strong opposition between the cultural sphere of the village and the wild areas beyond, es- 
pecially uninhabited marshes and forests - uninhabited by humans that is-because this is the home of the giants, monsters, elves and dwarves" who cause disease. ${ }^{37}$ Lacnunga therefore prescribes "a holy drink against tricks of elves and against every temptation of the fiend," and Leechbook a salve "against the race of elves and nightwalkers." Often the charms oppose female magic: the malign creatures to be battled in "Against a Sudden Stitch" are supernatural women, and another Lacnunga charm against tumors, scrofula, and worms describes the swellings as Noththe's nine sisters. To Glosecki such spirits, sisters to disir and valkyries, "are vaguely female, unpredictable, mostly evil, able to materialize out of nowhere and then disappear, usually after causing or predicting trouble.," 38

Those who enact these charms see themselves as warriors fighting supernatural foes, and when we look through their eyes we may find it difficult to see any other reality. After all, we ourselves often envision medicine as a battle against disease, and so it is not without cause that even the most recent critics notice only an Anglo-Saxon medical man. But even as we read his traces in essentially male manuscripts, we must recognize the influence of gender on paradigms and modes of perception. When we find a woman speaking and acting within a gendered manuscript "frame" we must recognize both voice and frame for what they are. From Lacnunga's childbirth charms we can learn to discern the differences in imagery and magical acts which mark women's utterances, women's negotiation of the complex healing traditions of Anglo-Saxon England.

37. Nigel Barley, “Anglo-Saxon Magico-Medicine," Journal of the Anthropological Society of Oxford 3 (1972): 67-76, quote at 68. See also Marie Nelson, Structures of Opposition in
Old English Poems (Atlanta, 1989).

38. Glosecki (n. 5 above), p. 66. 
Copyright of Modern Philology is the property of University of Chicago Press and its content may not be copied or emailed to multiple sites or posted to a listserv without the copyright holder's express written permission. However, users may print, download, or email articles for individual use. 